\title{
Correction: Int J Gynecol Cancer 2021; 31: multiple articles
}

The correct affiliation for the authors affiliated with the European Institute of Oncology should be the following: Department of Gynecologic Oncology, IEO, European Institute of Oncology IRCCS, Milan, Italy. This correction has been made to the following articles:

Glaser G, Dinoi G, Multinu F, et al. Reduced lymphedema after sentinel lymph node biopsy versus lymphadenectomy for endometrial cancer. Int J Gynecol Cancer 2021;31:85-91.

Boria F, Chiva L, Zanagnolo V, et al. Radical hysterectomy in early cervical cancer in Europe: characteristics, outcomes and evaluation of ESG0 quality indicators. Int J Gynecol Cancer 2021;31:1212-19.

Casarin J, Bogani G, Multinu F, et al. Paradigm shifts in gynecologic oncology. Int J Gynecol Cancer 2021;31:1617.

(C) Author(s) (or their employer(s)) 2022. No commercial re-use. See rights and permissions. Published by BMJ. Int J Gynecol Cancer 2022;0:1. doi:10.1136/ijgc-2021-vol31-corr1

(A) Check for updates 